\title{
Pengaruh Permainan Tradisional Terhadap Pengembangan Gerak Dasar Siswa SD Negeri 196/1V Kota Baru Kota Jambi
}

\author{
Boy Indrayana, S.Pd,. M.Pd \\ Correspondence: Fakultas Ilmu Keolahragaan, Universitas Jambi, \\ Jambi, Indonesia. \\ E-mail: boy_indrayana@unja.co.id
}

\begin{abstract}
Abstrak
Kebugaran jasmani erat kaitannya dengan kegiatan manusia melakukan pekerjaan dan bergerak. Penelitian ini bertujuan untuk melihat pengaruh permaian tradisional terhadap kemampuan gerak dasar dan kemampuan lari lompat. Untuk melihat pengaruh permaianan tradisioanl terhadap kemampuan lompat Siswa Putra SD Negeri 196/IV Kota baru Kota Jambi Tahun Ajaran 2013/2014. Metode Penelitian ini menggunakan metode eksperimen, hasil Uji statistik yang digunakan adalah t-test yaitu melihat pengaruh rerata hitung dalam satu kelompok yang sama pada taraf signifikan 0,05. Hasil tes awal (pre test) kamampuan gerak dasar siswa putra SD Negeri 196/IV Kota Baru Kota Jambi dengan jumlah sampel 30 orang, dari hasil analisi tes awal diperoleh nilai tertinggi 308,66, skor terendah 194,36, rata-rata (mean) 250, dan simpangan baku (SD) 28,71. Selanjutnya hasil tes akhir (post test) kemampuan gerak dasar setelah perlakuan diperoleh skor tertinggi 368,52, skor terendah 249,28, rata-rata (mean) 306,94, simpangan baku (SD) 27,88. Kesimpulan permainan tradisional memberikan pengaruh yang signifikan terhadap kemampuan gerak dasar siswa putra SD Negeri 196/IV Kota Baru Kota Jambi. Peningkatan kemampuan gerak dasar siswa putra SD Negeri 196/IV Kota Baru Kota Jambi ini adalah sebesar 56,94, yaitu dari skor rata-rata 250 pada pre test menjadi 306,94 pada post test Tahun Ajaran $2013 / 2014$
\end{abstract}

\section{Kata Kunci : Permainan Tradisional, Kemampuan Gerak Dasar}

\section{Pendahuluan}

Aktivatas fisik yang di lakukan khususnya pada tahap awal pembelajaran secara formal tentuanya di dapat pada usia dini tentenya pada sekolah dasar dalam hal ini akan mengenal beberapa gerakan olahraga yang berbentuk permainan kecil atau permainan tradisional dan aktivitas kesegaran jasmani. Olahraga adalah bentuk-bentuk kegiatan jasmani yang teratur yang terdapat didalam permainan, perlombaan, dan kegiatan jasmani yang intensif dalam rangka memperoleh rekreasi,

Kebugaran jasmani erat kaitannya dengan kegiatan manusia melakukan pekerjaan dan bergerak. Kita menyadari bahwa kebugaran jasmani yang baik dapat meningkatkan kinerja. Seseorang yang tidak memiliki kebugaran jasmani yang baik tidak akan mampu bekerja berat dalam tekanan untuk waktu yang relatif lama, dibandingkan dengan orang yang memiliki derajat kebugaran jasmani yang prima.

Dalam aktivitas yang dilakukan di sekolah khususnya di SD Negeri 196 /1V Kota Baru tentunya banyak aktivitas salah satunya melaluhui pendidikan jasmani dan kesehatan dengan ini akan mengarah kepada kebugaran jasmani yang 
baik menunjukkan kualitas seseorang, bukan hanya atlet tapi juga semua lapisan masyarakat seperti anak sekolah, para pekerja, dan juga lanjut usia. Semua dituntut untuk memiliki physical fitness, Apakah mereka berada disekolah, diperkantoran, pabrik-pabrik, atau tempat kerja lainnya, kesehatan dan kebugaran merupakan prakondisi mewujudkan kinerja yang optimal.

Kesegaran jasmani sangat dibutuhkan oleh siswa untuk memperoleh ketangkasan, berlari melempar, melompat dan menolak kesaggupan serta kemampuan belajar yang lainya. Dalam upaya meningkatkan kebugaran jasmani siswa perlu diberikan latihan fisik salah satu bentuk latihan fisik yang dapat diberikan adalah latihan kelincahan, di karenakan kelincahan merupakan salah satu komponen kebugaran jasmani.

Menurut Ismaryati (2008: 57), Kelincahan adalah kemampuan untuk mengubah arah dan posisi tubuh atau bagian-bagiannya secara tepat dan tepat. Sesuai dengan karakteristik siswa SD usia 6-12 tahun kebanyakan mereka cenderung masih suka bermain.

Dengan bermain mereka melakukan aktivitas fisiknya, sebenarnya mereka bermain tidak sekedar melibatkan fisiknya saja, tetapi melibatkan pula kejiwaannya. Di dalam memenuhi hasrat bergerak pada siswa, perlu memperhatikan karakteristik anak baik dari segi fisik mental, maupun sosial emosional. Besar kecilnya naluri bergerak bagi siswa tidak selalu sama. Dorongan bergerak tidak dapat diajarkan, tetapi merupakan pembawaannya masing-masing. Pendidik hanya dapat memberikan kesempatan dan mengarahkan dorongan gerak terutama sekali dalam gerak multilateral.

Gerak yang dilakukan dalam permainan tradisional, Kelincahan berkembang akan memberikan landasan yang kuat bagi dan keterampilan fungsi motorik, sehingga membentuk keseluruhan. Mengubah arah adalah penyebab umum dari cedera, sehingga dengan mengajar orang gerakan yang tepat mekanika kita mungkin dapat mengurangi risiko cedera. Belajar untuk menjadi tangkas memerlukan pengembangan pola gerakan yang sesuai. Anak-anak mulai mengembangkan keterampilan lokomotor pada usia dini seperti yang dapat diamati saat anak lucu, upaya untuk menghindari orang tua mengejar mereka di sekitar halaman. Hal ini dapat terlihat jelas namun bahwa efisiensi gerakan yang miskin, seringkali diasosiasikan dengan gerakan lengan canggung, secara keseluruhan tidak seimbang sikap, dan kurangnya umum waktu dan koordinasi. Menerapkan strategi untuk mengajar keterampilan motorik yang tepat dapat dimulai sekitar 5 tahun dengan periode kritis pengembangan terjadi antara 9 dan 12 tahun.

Dengan memberikan permainan yang menarik perhatian mereka, maka dapat menyalurkan keterampilan motorik terutama dalam gerak dasar kearah yang bermanfaat dan mengarah kepada aktivitas olahraga atau pembinaan gerak pada usia dini yang mengarah kecabang olahraga.

Berdasarkan uraian di atas, bahwa dalam kematangan gerak akibat aktivitas yang di lakukan anak didik di sekolah tentunya banyak sekali aktivitas yang di laukukan baik itu dalam bentuk olahraga atau aktivitas lainya dalam pemebelajaran pendidikan jasmani atau melaluhui pembinaan olahraga yang di

PJKR_

http://jurnal.unimed.ac.id/2012/index.php/jpehr/index 
lakukan kepada anak didik untuk berprestasi. Permainan tradisional tentuknya akan berdapak kepada tingkat perkembangan gerak dasar. Tujuan yang ingin dicapai melalui penelitian ini adalah untuk melihat pengaruh permaian tradisional terhadap kemampuan gerak dasar Siswa Putra SD Negeri 196/IV Kota baru Kota Jambi Tahun Ajaran 2013/2014.

\section{Pustaka}

Permainan tardisional adalah permainan yang dimainkan oleh anak-anak Indonesia dengan berbagai bentuk permaianan sesuai daerahnya masing -masing baik pakai alat maupun tanpa alat, dengan permainan yang sederhana, tanpa mesin, bahkan ada yang hanya bermodal badan sehat. Maksudnya, asalkan anak tersebut sehat, maka anak bisa ikut bermain. Jenis permainan ini juga sering disebut dolanan.

Permainan tradisional adalah permainan yang mempunyai makna dengan nilai-nilai dan norma-norma luhur yang berguna bagi anak-anak untuk memahami dan mencari keseimbangan dalam tatanan kehidupan. Oleh karena itu, Permainan tradisional yang diciptakan oleh leluhur bangsa ini pun berdasar atas banyak pertimbangan dan perhitungan. Hal ini karena leluhur kita mempunyai harapan agar nilai-nilai yang disisipkan pada setiap permainan tersebut dapat dilaksanakan anak-anak dalam setiap tindakan dan perbuatannya dengan penuh kesadaran atau tanpa adanya paksaan. Anak-anak dalam bermain permainan tradisional ini tidak tergantung pada alat, karena permainan tradisional bisa dilakukan dengan alat dan tanpa alat menyesuakikan dengan keadaan yang ada.atau dimana kondisi lapangan dan lingkunganya sangat mendukung.

Berdasarkan beberapa teori permainan bagi anak maka semua anak harus mempunyai kesempatan yang sama untuk mengikuti macam - macam permainan. Banyak permainan yang membutuhkan gerak lokomotor dan meyediakan sarana yang meyenangkan untuk berlatih gerakan - gerakan. Gerak dalam suatu permainan dapat di capai suatu tujuan dari ranah psikomotor. Antara lain adalah Ranah psikomotor, Ranah kognitif, Ranah afektif

Ada beberapa bentuk permainan taradisional yang dalam pelaksanaanya mempunyai aturan dan sikap sportif spontan yang di awal dengan peraturan yang di sepakati sebelum permainan, di antara lain permainanya sebagai berikut: Permainan Hadang, permainan hadang adalah suatu permainan yang dimainkan oleh dua orang regu putra atau putri masing-masing regu terdiri dari lima orang. Permainan dimainkan $2 \times 20$ menit dan istirahat 5 menit. Permainan dipimpin oleh 2 orang wasit dan dibantu 2 orang penjaga garis dan 2 orang pencatat nilai, kedua wasit mempunyai tugas, fungsi, dan wewenang yang sama, wasit member tanda dengan membunyikan peluit. Penjaga garis memberikan tanda dengan mengangkat bendera.

Permainan Kupu-Kupu Hinggap, permainan kupu-kupu hinggap adalah permainan yang dimainkan oleh dua kelompok atau lebih yang masing-masing kelompok terdiri dari 15-30 orang dan dipecahkan lagi menjadi satu kelompok yang masing-masing terdiri dari 3 orang, tetapi ini bukan syarat pokok dan tidak begitu dipermasalahkan karena jumlah peserta yang ingin ikut bermain bisa lebih

PJKR_

http://jurnal.unimed.ac.id/2012/index.php/jpehr/index 
dari 40 orang. Tujuan utama permainan ini adalah untuk melatih kerja dari otak kiri agar dapat bergerak cepat dengan adanya rangsangan dalam permainan kupukupu hinggap ini, serta melatih kelincahan gerak dari kejaran si penangkap kupukupu agar tidak tetangkap maka kupu-kupu dapat hinggap di antara kelompokkelompok kecil yang terdiri dari 2 orang. (Soemitro : 1992 : 175).

Permainan Gajah Ngamuk, permainan kecil gajah ngamuk adalah permainan yang jumlah pesertanya tidak terbatas tergantung jumlah anak yang ada di sekolah dan peserta permainan ini boleh anak laki-laki dan perempuan yang berusia 7-12 tahun atau lebih. Dalam permainan ini tidak mengunakan alat. Tempat permainan biasa di bangsal senam, halaman sekolah atau lapangan yang harus diberikan pembatas lapangan. Permainan kecil gajah ngamuk ini sangat membutuhkan kelincahan sesuai dengan tujuan utama permainan ini adalah melatih kelincahan gerak dari kejaran si gajah ngamuk agar tidak tetangkap. (Soemitro, Permainan Kecil :1992).

Dalam perkembanagan manusia gerak sangat di butuhkan untuk berkerja dan memepertahankan hidupnya, dari amcaman yang datang dari lingkunganya. Tanpa kemampuan gerak, manusia sulit untuk mendapatkan kelangsungan hidup, gerak dikatakan mempunyai nilai strategis bagi kehidupan manusia. Pada hakikatnya manusia dibangun oleh empat komponen dasar: Kognitif, Motorik, Afektif, dan Emosional (Yanuar Kiram: 2000:7).

Aktivitas gerak terjadi akibat dari proses adaptasi lingkungan sekitarnya dan stimulus yang ia lihat, sehingga menimbulkan gerak dari proses tersebut. Untuk itu dalam hal ini tentunya gerak yang di lakukan merupakan akibat apa yang mereka lihat dan kebutuhan apa yang mereka rasakan sehingga akan menimbulkan aktivitas lain dalam memenuhui kebutuhan hidup mulai dari usia anak-anak sampai dewasa khususnya dalam aktivitas bermain olahraga atau permainan tradisional. Pembelajaran gerak di sini kembanyakan proses yang terjadi akibat dari pemenuhui kebutuhan hidup khususnya pada anak sekolah dasar, dalam usia tidak menjadi persolan di karnakan oleh tuntutan dari kondisi lingkungan yang ada dari proses belajar khususnya pembelajaran pendidikan jasmani.

Kata kemampuan motorik merupakan terjemahan dari motor ability. Istilah motor ability sering terjadi pencampuradukan pengunaan istilahnya dengn athltic ability. Sebenarnya kedua istilah tersebut berbeda, yaitu istilah motor mengacu kepada gerakan fisik, sedangkan athtltic ability mengacu kepada gerakan fisik komplek olahraga (Gusril, 2008:12).

Menurut Lutan dalam Gusril (2008:12), menyatakan kemampuan motorik di katakan kualitas kemampuan seseorang yang dapat mempermudah dalam keterampilan gerak. Pengembangan kemampuan gerak dari mulai kemampuan gerak dasar, kemampuan gerak tertentu sampai kemampuan gerak khusus yang di pengaruhui faktor tampilan dan faktor lingkungan. Babang Sujiono dkk, (2007: 328), kemampuan gerak dasar secara bersama di pengaruhui, kematangan gerak secara tidak sadar di proses oleh aktivitas yang di lakukan tersebut, karna berkaitan dengan kebutuhan hidup dalam bergerak khususnya di sekolah dalam melakukan aktivitas. 
Pengembangan kemampuan gerak, motivasi untuk bergerak mungkin karena adanya stimulus dari aktivitas yang di lakukan anak didik, misalnya melihat benda atau mainan menarik maka seseorang akan menuju ke arah benda, sebaliknya terbatasnya kesempatan untuk bergerak secara aktif akan memperlambat perkembangan gerak anak.

Menurut Harsuki (2003:70) menyatakan Movement (gerakan) apabila kamu bergerak bagian apa dari tubuh anda dapat bergerak dengan kualitas yang dapat terkontrol. Dengan suatu eksperimen bagian tertentu dapat berputar dengan pelan, cepat, tinggi, lemah, kuat, lembut, besar, kecil dan sebaginnya. Gerak dalam pendidikan jasmani seluas gerak kehidupan sehari-hari mulai dari merayap, merangkak, melompat, berjalan, berlari, memajat, berayun, berguling, berjingkat, menggedong, melempar, menangkap, memukul, mengangkat, menahan, mendorong, menarik dan seterusnya.

Kesegaran jasmani merupakan aspek yang sangat penting dari kebugaran jasmani secara keseluruhannya, yang nantinya akan memberikan kesanggupan pada seseorang untuk menjalani hidup yang produktif serta dapat menyesuaikan diri setiap beban fisik yang layak, (Sutarman, 1975). Ahli fisiologi berpendapat bahwa kesegaran jasmani lebih dititik beratkan pada physiological fitness yaitu kemampuan tubuh untuk menyesuaikan fungsi alat-alat tubuhnya dalam batasbatas fisiologis terhadap keadaan lingkungan dan kerja fisik dengan cara yang cukup efesien tanpa lelah secara berlebihan, sehingga masih dapat melaksanakan kegiatan-kegiatan lain yang bersifat rekreatif dan telah mengalami pemulihan yang sempurna sebelum datangnya tugas yang sama esok harinya.(Soedjatmo Soemowerdjo dalam Ismaryati : 2008 : 39-40).

Tingkat kesegaran jasmani sangat penting dan sesuai dengan kebutuhan siswa yang selalu dihadapkan dengan kegiatan jadwal pelajaran yang padat, karena bila kebugaran jasmani meningkat akan dapat memberikan hal yang berarti terhadap ketahanan jasmaniah. Seseorang memiliki tingkat kesegaran jasmani yang tinggi akan memiliki kekuatan dan ketahanan untuk melakukan aktifitas kehidupan tanpa mengalami kelelahan yang berarti. Dari penjelasan diatas dapat dikemukakan bahwa kesegaran jasmani merupakan faktor penentu dalam segala aspek kehidupan. Seorang yang memiliki tingkat kesegaran jasmani yang tinggi atau tingkat kondisi tubuh yang prima akan dapat melakukan aktivitas yang lama dengan beban yang cukup, tanpa mengalami kelelahan yang berarti. Kebugaran jasmani tersebut meliputi: Kelincahan (Agility), Keseimbangan (Balance), Kecepatan (Speed), Kelentukan, Kekuatan (Strenght), Daya tahan otot (Endurance), Kekuatan eksplosif / Daya ledak (Power), Daya tahan jantung, peredaran darah dan pernafasan (Cardiovaskular Endurance).

Dalam permainan tradisional gerak anak sangat di butuhkan sekali seperti kelincahan merupakan salah satu komponen fisik yang banyak dipergunakan dalam olahraga. Kelincahan pada umumnya didefinisikan sebagai kemampuan

PJKR_

http://jurnal.unimed.ac.id/2012/index.php/jpehr/index 
mengubah arah secara efektif dan cepat, sambil berlari hampir dalam keadaan penuh.

Kelincahan terjadi karena gerakan tenaga yang ekplosif. Besarnya tenaga ditentukan oleh kekuatan dari kontraksi serabut otot. Kecepatan otot tergantung dari kekuatan dan kontraksi serabut otot. Kecepatan kontraksi otot tergantung dari daya rekat serabut-serabut otot dan kecepatan transmisi impuls saraf. Kedua hal ini merupakan pembawaan atau bersifat genetis, atlet tidak dapat merubahnya (Baley, James A. (1986: 198). M. Sajoto (1995: 90) mendefinisikan kelincahan sebagai kemampuan untuk mengubah arah dalam posisi di arena tertentu. Seseorang yang mampu mengubah arah dari posisi ke posisi yang berbeda dalam kecepatan tinggi dengan koordinasi gerak yang baik berarti kelincahannya cukup tinggi. Sedangkan menurut Dangsina Moeloek dan Arjadino Tjokro (1984: 8), kelincahan adalah kemampuan mengubah secara cepat arah tubuh atau bagian tubuh tanpa gangguan pada keseimbangan.

Mengubah arah gerakan tubuh secara berulang-ulang seperti halnya lari bolak balik memerlukan kontraksi secara bergantian pada kelompok otot tertentu. Sebagai contoh saat lari bolak-balik seorang atlet harus mengurangi kecepatan pada waktu akan mengubah arah. Untuk itu otot perentang otot lutut pinggul (knee ekstensor and hip ekstensor) mengalami kontraksi eksentris (penguluran), saat otot ini memperlambat momentum tubuh yang bergerak ke depan. Kemudian dengan cepat otot ini memacu tubuh ke arah posisi yang baru. Gerakan kelincahan menuntut terjadinya pengurangan kecepatan dan pemacuan momentum secara bergantian. Rumus momentum adalah massa dikalikan kecepatan. Dari beberapa pendapat tersebut tentang kelincahan dapat ditarik pengertian bahwa kelincahan adalah kemampuan seseorang untuk mengubah arah atau posisi tubuh secara cepat dan efektif di arena tertentu tanpa kehilangan keseimbangan. Seseorang dapat meningkatkan kelincahan dengan meningkatkan kekuatan otot-ototnya. Kelincahan biasanya dapat dilihat dari kemampuan bergerak dengan cepat, mengubah arah dan posisi, menghindari benturan antara pemain dan kemampuan berkelit dari pemain di lapangan. Kemampuan bergerak mengubah arah dan posisi tergantung pada situasi dan kondisi yang dihadapi dalam waktu yang relatif singkat dan cepat.

Berkaitan dengan hal di atas, kelincahan dibedakan menjadi kelincahan umum yang biasanya nampak pada berbagai aktivitas olahraga dan kelincahan khusus yang berkaitan dengan teknik gerakan olahraga tertentu. Jika ditinjau dari sudut anatomis kelincahan umum melibatkan gerakan seluruh segmen bagian tubuh dan kelincahan khusus hanya melibatkan segmen tubuh tertentu.

\section{Metode}

Metode penelitian adalah eksperimen, dalam peneitian ini kelompok eksperimen yang sengaja diberi perlakuan. Adapun rancangan penelitian ini menggunakan rancangan One Group Pretest-Posttest Design yaitu satu kelompok 
yang diberikan perlakuan, tetapi sebelum perlakuan diberikan terlebih dahulu dilakukan tes awal (pretest), kemudian diakhir perlakuan dilakukan tes akhir (posttest). Penelitian dilaksanakan di lapangan dilingkungan SD Negeri 196/IV Kota baru kota Jambi. Adapun populasi dalam penelitian ini adalah keseluruhan Siswa putra kelas 3 Sampai 5 . SD Negeri 196/IV Kota baru Kota Jambi yang berjumlah 30 orang.

Tabel 1. Jumlah Siswa Putra SD Negeri 196/IV Kota Jambi

\begin{tabular}{|c|c|c|}
\hline No & Kelas & Jumlah siswa putra \\
\hline 1 & III & 12 \\
\hline 2 & IV & 8 \\
\hline 3 & V & 10 \\
\hline \multicolumn{2}{|c|}{ Jumlah } & 30 \\
\hline
\end{tabular}

Instrumen pengukuran kemampuan motorik terdiri dari setiap variable yang di amati meliputi prosedur yang di perlukan antara lain kemampuan gerak dasar Barrow Motor Abilty Test dari Barry L Johnson and Jack K Nelson (1986:365), meliputi: Standing Long Jump (lompat jauh tanpa awalan), lari menyamping, Shuttle Run. Perlengkapan: Stopwatch, meteran, kons, pita atau isolasi berwarna untuk membuat garis start, cat atau kapur untuk membuat tanda arah lari, peluit, alat tulis, petugas, dll.

Teknik pengumpul data diawali dengan tes awal awal dari kemampuan motorik. Tujuan tes ini adalah untuk mengukur kemampuan Peserta test berdiri sedekat mungkin di belakang garis start, kemudian melakukan lompatan begitu juga dalam lempar bola kediding sambil duduk. Perlakuan permainan tradisional ini dilakukan sebanyak 18 kali pertemuan dengan frekuensi 3 kali seminggu. Suatu latihan baru akan memberi efek setelah enam minggu, dimana terlihat kemampuan 30\% apabila dilakukan 3 kali seminggu". (Kusuma dalam Ali: 1991).

Analisis data, dari hipotesis yang diajukan, analisis data dilakukan dengan menggunakan uji t guna melihat hasil eksperimen yang menggunakan pre-tes dan post-test one group design, namun terlebih dahulu dilakukan uji normalitas dan homogenitas. Uji hipotesis menggunakan uji t pada taraf kepercayaan $95 \%$ atau $\alpha$ $=0,05$ dengan menggunakan rumus sebagi berikut: $\mathrm{Uji}-\mathrm{t}$

\section{Pembahasan}

Data daya tahan hasil tes awal

Berdasarkan analisis data tes awal (pre test) kemampuan gerak dasar pada tes gerak dasar dengan jumlah sampel 30 diperoleh skor tertinggi 308,66, skor terendah 194,36, rata-rata (mean) 250, dan simpangan baku (SD) 28,71. untuk lebih jelasnya dapat dilihat pada tabel distribusi frekuensi di bawah ini:

PJKR_

http://jurnal.unimed.ac.id/2012/index.php/jpehr/index 
Tabel 2. Distribusi Frekuensi Tes Awal

\begin{tabular}{|c|c|c|c|c|c|c|}
\hline \multirow{2}{*}{ No } & \multirow{2}{*}{\multicolumn{3}{|c|}{$\begin{array}{c}\text { Kelas Interval } \\
\text { Kemampuan gerak dasar }\end{array}$}} & \multicolumn{2}{|c|}{ Frekuensi } & \multirow{2}{*}{ Klasifikasi } \\
\hline & & & & $\mathrm{Fa}$ & Fr & \\
\hline 1 & \multicolumn{3}{|c|}{$>293,07$} & 2 & 6,67 & Baik Sekali \\
\hline 2 & 264,37 & _ & 293,07 & 8 & 26,67 & Baik \\
\hline 3 & 235,64 & - & 264,36 & 10 & 33,33 & Sedang \\
\hline 4 & 206,93 & - & 235,65 & 7 & 23,33 & Kurang \\
\hline 5 & \multicolumn{3}{|c|}{$<206,94$} & 3 & 10,00 & Kurang Sekali \\
\hline \multicolumn{4}{|c|}{ Jumlah } & 30 & 100 & \\
\hline
\end{tabular}

\section{Data daya tahan tes akhir}

Hasil tes akhir (post test) kemampuan gerak dasar dengan jumlah sampel 30 orang diperoleh skor tertinggi 48,5, skor terendah 30,6, rata-rata (mean) 38,732 , , simpangan baku (SD) 5,51. Untuk lebih jelasnya dapat dilihat pada tabel di bawah ini:

Tabel 3. Distribusi Frekuensi Tes Akhir.

\begin{tabular}{|c|c|c|c|c|c|c|}
\hline \multirow{2}{*}{ No } & \multirow{2}{*}{\multicolumn{3}{|c|}{$\begin{array}{c}\text { Kelas Interval } \\
\text { Kemampuan gerak dasar }\end{array}$}} & \multicolumn{2}{|c|}{ Frekuensi } & \multirow{2}{*}{ Klasifikasi } \\
\hline & & & & $\mathrm{Fa}$ & $\mathrm{Fr}$ & \\
\hline 1 & \multicolumn{3}{|c|}{$>293,07$} & 22 & 73,33 & Baik Sekali \\
\hline 2 & 264,37 & \multirow{3}{*}{$\begin{array}{l}- \\
- \\
-\end{array}$} & 293,0691 & 8 & 26,67 & Baik \\
\hline 3 & 235,6436 & & 264,3564 & 0 & 0,00 & Sedang \\
\hline 4 & 206,9309 & & 235,65 & 0 & 0,00 & Kurang \\
\hline 5 & \multicolumn{3}{|c|}{$<206,94$} & 0 & 0,00 & Kurang Sekali \\
\hline \multicolumn{4}{|c|}{ Jumlah } & 30 & 100 & \\
\hline
\end{tabular}

Dari tabel di atas dapat dilihat bahwa pada hasil post test 22 orang (73,33\%) memiliki kemampuan gerak dasar pada kelas interval >293,07 dan dikategorikan baik sekali dan 8 orang $(26,67 \%)$ memiliki kemampuan gerak dasar pada kelas interval 264,37 - 293,07 dan dikategorikan baik sedangkan pada kategori sedang, kurang dan kurang sekali tidak dimiliki pada tes akhir.

Dari hasil pengolahan data uji Normalitas dengan Uji Liliefours diperoleh angka normalitas distribusi data seperti pada tabel berikut:

Tabel 4. Rangkuman Hasil Pengujian Normalitas Data

\begin{tabular}{|c|c|c|c|c|}
\hline Data & $\mathbf{N}$ & Lo & L tabel & Ket \\
\hline (Pre test) & 30 & 0,07 & 0,161 & Normal \\
\hline (Post test) & 30 & 0,113 & 0,161 & Normal \\
\hline
\end{tabular}

Uji homogenitas dilakukan untuk melihat apakah data penelitian memiliki varians yang sama (homogen) atau tidak. Hasil analisis data diperoleh homogenitas data sebagai berikut:

Tabel 5. Rangkuman Hasil Uji Homogenitas Varians

\begin{tabular}{|l|c|c|c|c|}
\hline Data & $\mathbf{N}$ & $\mathbf{F}_{\mathbf{h}}$ & Ftabel & Ket \\
\hline
\end{tabular}

PJKR_

http://jurnal.unimed.ac.id/2012/index.php/jpehr/index 


\begin{tabular}{|c|c|c|c|c|}
\hline $\begin{array}{c}\text { Tes Awal (Pre Test) } \\
\text { dan } \\
\text { Tes Akhir (Pos Test) }\end{array}$ & 30 & 0,94 & 1,85 & Homogen \\
\hline
\end{tabular}

Tabel di atas menunjukkan bahwa pada tes awal (pre test) nilai $\mathrm{F}_{\text {hitung }}$ adalah 0,94 sedangkan $\mathrm{F}$ tabel dengan menggunakan derajat kebebasan (n1-1), (n2-1) dan dengan taraf signifikansi probability pada setiap variabel lebih besar dari 0,05 , jadi didapat $\mathrm{F}$ tabel= 1,85 dengan demikian berarti bahwa data penelitian ini adalah homogen, ini dikarenakan $\mathrm{F}$ hitung $<\mathrm{F}$ tabel yaitu $0,94<1,85$. Sedangkan pada tes akhir (post test) terlihat bahwa nilai $\mathrm{F}$ hitung adalah 0,94 sedangkan $\mathrm{F}$ tabel dengan menggunakan derajat kebebasan (n1-1), (n2-1) dan dengan taraf signifikansi probability pada setiap variabel lebih besar dari 0,05 , jadi didapat $\mathrm{F}$ tabel $=1,85$ dengan demikian berarti bahwa data penelitian ini adalah homogen, ini dikarenakan $\mathrm{F}_{\text {hitung }}<\mathrm{F}$ tabel yaitu $0,94<1,85$.

Tabel 6. Rangkuman Hasil Pengujian Hipotesis

\begin{tabular}{|c|c|c|c|c|c|c|c|}
\hline Hasil & Mean & SD & $\mathbf{t}_{\text {hitung }}$ & $\mathbf{A}$ & $\mathbf{t}_{\text {tabel }}$ & Hasil Uji & Keterangan \\
\hline Pre Test & 250 & 28,71 & 28,97 & 0,05 & 1,699 & Signifikan & $\begin{array}{c}\text { Ho ditolak } \\
\text { Ha diterima }\end{array}$ \\
\hline
\end{tabular}

Berdasarkan tabel di atas dapat dilihat bahwa $t_{\text {hitung }}(28,97)>t_{\text {tabel }}(1,699)$. Hal ini berarti bahwa hipotesis penelitian dapat diterima. Dengan demikian dapat disimpulkan bahwa permainan tradisional memberikan pengaruh yang signifikan terhadap kemampuan gerak dasar siswa putra SD Negeri 196/IV Kota Baru Kota Jambi. Peningkatan kemampuan gerak dasar siswa putra SD Negeri 196/IV Kota Baru Kota Jambi ini adalah sebesar 56,94, yaitu dari skor rata-rata 250 pada pre test menjadi 306,94 pada post test.

Melihat masalah pada siswa putra SD Negeri 196/IV Kota Baru Kota Jambi yaitu rendahnya kemampuan gerak dasar, maka perlu dilakukan latihan untuk meningkatkan kemampuan gerak dasar. Dalam hal ini latihan yang diberikan adalah dengan menggunakan permainan tradisional. Dari penggunaan permainan ini akan dilihat apakah ada pengaruh terhadap kemampuan gerak dasar siswa putra SD Negeri 196/IV Kota Baru Kota Jambi.

Sebelum eksperimen diberikan kepada sampel, terlebih dahulu dilakukan tes awal (pre test) guna memperoleh data awal. Untuk mendapatkan data yang lebih akurat maka perlu kiranya dilakukan pengkajian tentang metodologi dan kajian teori yang mendukung terhadap suatu penelitian. Dengan menggunakan pengetahuan yang diperoleh melalui pendekatan ilmiah dan dibuat berdasarkan teori tertentu serta dilakukan dalam suatu metode yang sistematis dengan langkahlangkah maupun prosedur yang benar, maka diharapkan hasil penelitian ini dapat diterima kebenarannya. Melalui hasil pengujian hipotesis penelitian ini terdapat pengaruh dari permainan tradisional terhadap kemampuan gerak dasar menunjukkan bahwa terhadap perbedaan pengaruh yang signifikan antara hasil

PJKR_

http://jurnal.unimed.ac.id/2012/index.php/jpehr/index 
pre test dengan post test. Hal ini menggambarkan bahwa permianan tradisional memberikan pengaruh yang berarti terhadap kemampuan gerak dasar.

Berdasarkan kajian teori diatas, permainan tradisional tersebut pada prinsip geraknya hampir sama gerak dasar seperti melompat, meloncat dan berlari. Dengan demikian secara tidak langsung permainan merupakan salah satu bentuk latihan yang dapat digunakan untuk meningkatkan kemampuan gerak dasar siswa Sekolah Dasar.

Pada hakikatnya manusia sejak lahir mengalami perubahan-perubahan, baik juga perubahan yang bersifat kualitatif dan kuantitatif. Perubahan-perubahan tersebut dapat berupa pertumbuhan dan perkembangan. Dalam penelitian ini perkembangan terjadi pada kemampuan gerak. Perkembangan gerak dapat pula disebut motor development. Menurut Waharsono (1999:5) bahwa: "Perkembangan gerak atau motor development adalah suatu proses sejalan dengan bertambahnya usia dimana secara bertahap dan berkesinambungan gerakan individu meningkat dari keadaan sederhana, tidak terorganisasi dan tidak terampil kearah penampilan keterampilan gerak yang kompleks dan terorganisasi dengan baik, yang pada akhirnya kearah penyesuaian keterampilan menyertai terjadinya proses menua (menjadi tua) dalam kehidupan normal". Dengan menerapkan permainan traadisional dapat meningkatkan kemampuan gerak dasar. Dalam permainan tradisional gerak anak sangat di butuhkan agar dapat memenangkan permainan. Oleh karena itu, latihan meningkatkan kemampuan motorik dalam bentuk permainan tradisional dapat meningkatkan motivasi dan semangat kepada siswa. Karena dalam permainan tradisional siswa merasa tidak dibebankan dalam meningkatkan kemampuan gerak dasar. Selain itu, siswa juga merasa senang dalam melakuan permainan tradisional tersebut.

\section{Simpulan}

Berdasarkan hasil penelitian dan pembahasan dapat dikemukakan kesimpulan bahwa permainan tradisional berpengaruh secara signifikan terhadap peningkatan kemampuan gerak dasar, dari rata-rata tes awal 250 menjadi 306,94 pada tes akhir, dengan beda mean sebesar 56,94 $\left(\mathrm{t}_{\text {hitung }}=28,97>\mathrm{t}_{\text {tabel }}=1.161\right)$.

\section{Rujukan}

A. Muri Yusup, 1985. Prosedur Penelitian. Bandung: Angkasa.

Arikunto Suharsimi, 2002. Prosedur Penelitian. Jakarta: Rineka Cipta.

Brian J. Sharkey, Phd, 2003. Kebugaran dan Kesehatan. Jakarta: PT Raja Grafindo Persada

Burhan Bungin, 2003. Analisis Data Penelitian Kualitatif. Jakarta: PT Raja Grafindo Persada.

Fuad Ihsan, 2003. Dasar-dasar Kependidikan. Jakarta: Rineka Cipta.

PJKR_

http://jurnal.unimed.ac.id/2012/index.php/jpehr/index 
Gusril, 2004. Beberapa faktor yang berkaitan dengan kemampuan motorik siswa Sekolah dasar. Padang: UNP.

Gusril, 2009. Perkembang motorik pada masa anak-anak. Padang: UNP.

Ismaryati, 2008. Tes dan Pengukuran. Surakarta: LPP UNS.

Muhajir, 2003. Teori dan Praktik Pend. Jasmani. Bandung: Yudistira.

M. Yunus SB dan Rusli Luthan, 2004. Dasar-dasar Kepelatihan Olahraga. Jakarta: DEPDIKNAS.

Syarial, 2011. Pengaruh strategi pembelajaran dan lokasi sekolah terhadap kemampuan gerak dasar siswa sekolah dasar di kota padang. Padang: UNP.

Soemitro, 1992. Permainan tradisional. Jakarta: DEPDIKNAS.

Sudjana, 1992. Metode Statistika. Bandung: Tarsito.

Sugiono, 2009. Metode Penelitian Administrasi. Bandung: Alfabeta.

Sumadi Suryabrata, 2003. Metodologi Penelitian. Jakarta: Grafindo. , 2003. Tes Kesegaran Jasmani Indonesia. Jakarta: DEPDIKNAS. 